\title{
Electrodialytic desalination of brackish water: determination of optimal experimental parameters using full factorial design
}

\author{
Soumaya Gmar ${ }^{1} \cdot$ Nawel Helali $^{1}$ - Ali Boubakri ${ }^{2} \cdot$ Ilhem Ben Salah Sayadi $^{1}$. \\ Mohamed Tlili ${ }^{1} \cdot$ Mohamed Ben Amor ${ }^{1}$
}

Received: 22 March 2017/ Accepted: 29 August 2017/Published online: 15 September 2017

(c) The Author(s) 2017. This article is an open access publication

\begin{abstract}
The aim of this work is to study the desalination of brackish water by electrodialysis (ED). A two levelthree factor $\left(2^{3}\right)$ full factorial design methodology was used to investigate the influence of different physicochemical parameters on the demineralization rate (DR) and the specific power consumption (SPC). Statistical design determines factors which have the important effects on ED performance and studies all interactions between the considered parameters. Three significant factors were used including applied potential, salt concentration and flow rate. The experimental results and statistical analysis show that applied potential and salt concentration are the main effect for DR as well as for SPC. The effect of interaction between applied potential and salt concentration was observed for SPC. A maximum value of $82.24 \%$ was obtained for DR under optimum conditions and the best value of SPC obtained was $5.64 \mathrm{Wh} \mathrm{L}^{-1}$. Empirical regression models were also obtained and used to predict the DR and the SPC profiles with satisfactory results. The process was applied for the treatment of real brackish water using the optimal parameters.
\end{abstract}

Keywords Demineralization rate - Desalination . Electrodialysis - Full factorial design - Specific power consumption

Soumaya Gmar

soumayagmar@yahoo.com

1 Laboratory of Natural Water Treatment, Center of Researches and Water Technologies, P.B 273, 8020 Soliman, Tunisia

2 Laboratory of Waste Water Treatment, Center of Researches and Water Technologies, P.B 273, 8020 Soliman, Tunisia

\section{Introduction}

The shortage of drinking water is a major problem in the southern communities of Tunisia. In these regions, the traditional sources of fresh water are insufficient to meet the demand and are being stressed by competing uses, such as irrigation and industrial needs (Walha et al. 2007). However, in recent times and with the development of desalination processes, there has been an increasing interest in using brackish waters as a source of potable water. Desalination is a process that removes dissolved minerals from seawater or brackish water or treated waste water. These processes create more valuable water by converting saline waters into a resource (Reig et al. 2014; McGovern et al. 2014a; Tanaka et al. 2015). Several desalination methods have been developed to obtain fresh drinking water. There are mainly two families of desalination technologies used throughout the world today. They include thermal (evaporative) and membrane technologies. Membrane methods are less energy intensive than thermal methods and since energy consumption directly affects the cost effectiveness and feasibility of using desalination technology, membrane methods such as reverse osmosis (RO) and electrodialysis (ED) are attracting great attention lately (Sadrzadeh and Mohammadi 2008; McGovern et al. 2014b). ED is a membrane process for the separation of ions across charged membranes from one solution to another under the influence of an electrical potential difference used as a driving force (Sadrzadeh and Mohammadi 2008).

This process has been widely used to produce drinking water from brackish and sea water (Fidaleo and Moresi 2005; Lee et al. 2006; Jing et al. 2012; Galama et al. 2014; Zourmand et al. 2015; Reig et al. 2016a, b; Monohar et al. 2017). It has been also used in treatment of industrial 
effluents (Ghyselbrecht et al. 2013), purification of amino acids and other organic compounds (Elisseeva et al. 2002) and to remove heavy metals from waste water (Nemati et al. 2017).

Many factors influence the ED performance such as applied potential (Elmidaoui et al. 2002; Banasiak et al. 2007), salt concentration (Banasiak et al. 2007; Shady et al. 2012), flow rate of dilute compartment and temperature (Sadrzadeh and Mohammadi 2008; Ben Sik Ali et al. 2010a; Shady et al. 2012).

A literature survey revealed that DR was increased with the applied potential but it was decreased at high values of salt concentration (Banasiak et al. 2007; Sadrzadeh and Mohammadi 2008; Shady et al. 2012). Sadrzadeh and Mohammadi (2008) and Ben Sik Ali et al. (2010a) observed that the salt percent removal increases when the flow rates decrease. They suggested that for low flow rates the residence time of ions in the dilute compartment increases. On the other hand, Elmidaoui et al. (2002) demonstrated that DR increased with increasing flow rates. The authors attributed this result to the decrease in the thickness of the boundary layers adjacent to the membrane surfaces with increasing solution velocity.

In most previous studies, the effect of some parameters on ED process is determined by varying one parameter by time, maintaining all the other parameters constant (Elmidaoui et al. 2002; Kabay et al. 2008; Ben Sik Ali et al. $2010 \mathrm{a}, \mathrm{b})$. Then the best value achieved by this procedure is fixed and other parameters are varied by time. The disadvantage of this univariate procedure is that the best conditions cannot be attained, because the interaction effects between the parameters are discarded. Moreover, conventional methods are time consuming and require a large number of experiments to determine the optimum conditions. These drawbacks of the conventional methods can be eliminated by studying the effect of all parameters using a factorial design. In fact, this methodology determines which factors have significant effects on a response as well as how the effect of one factor varies according to the level of the other factors (Meski et al. 2011; Balbasi 2013; Azza et al. 2015). Its most important advantages are not only the effects of individual parameters but also the interaction of two or more variables can also be derived (Montgomery 2001). This is not possible in a classical one factor at a time of experiment.

Therefore, the aim of this work is to study the performance of the ED process on brackish water desalination. To be made, a $2^{3}$ full factorial design was used to investigate the effects of operating parameters (applied potential, flow rate and salt concentration) on the ED efficiency. This efficiency is evaluated by the demineralization rate (DR) and the specific power consumption (SPC). Experiments were carried out with synthetic solutions of $\mathrm{NaCl}$ at different concentrations for checking the optimal conditions. Then, real brackish water was treated by ED using the optimal conditions.

\section{Materials and methods}

\section{Chemicals reagents}

Analytical grade sodium chloride $(\mathrm{NaCl})$ and sodium sulphate $\mathrm{Na}_{2} \mathrm{SO}_{4}$ are used to produce solution with known amounts of salts and electrode rinse solution, respectively. $\mathrm{KCl}$ is used to calibrate conductivity cell. Ethylene diamine tetraacetic acid (EDTA), sulphuric acid $\left(\mathrm{H}_{2} \mathrm{SO}_{4},\right)$, barium chloride $\left(\mathrm{BaCl}_{2}\right)$, hydrochloric acid $(\mathrm{HCl})$ sodium hydroxide $(\mathrm{NaOH})$, sodium fluoride $(\mathrm{NaF})$ and glacial acid acetic $\left(\mathrm{CH}_{3} \mathrm{COOH}\right)$ are used to analyze the real water. Each solution was prepared using distilled water. All chemicals were purchased from Sigma-Aldrich.

\section{Real water sample}

Brackish water studied was sampled from the south of Tunisia during February 2013. The physicochemical characteristics of the sample water are given in Table 1. It is a brackish water of low salinity (total dissolved salts (TDS) $<3000 \mathrm{mg} \mathrm{L}^{-1}$ ). The fluoride concentration largely exceeds $1.5 \mathrm{mg} \mathrm{L}^{-1}$, the recommended value by World Health Organization (WHO). Moreover, the recommended values of $400 \mathrm{mg} \mathrm{L}^{-1}$ for sulphate and $250 \mathrm{mg} \mathrm{L}^{-1}$ for chloride are also exceeded. Therefore, this water is not suitable for drinking.

\section{Electrodialysis equipment and membranes}

The ED setup consists of a power DC, a concentrate reservoir, a dilute reservoir, a rinsing electrode reservoir and three pumps (Heidolph D-93309) equipped each with a flow-meter (PC Cell $\mathrm{GmbH})$ and three valves to control the feed flow rate in the compartment of ED cell. Figure 1 shows a simplified scheme of ED setup working in batch recirculation mode.

The ED cell was a PC Cell ED 64-004 (Germany) used as a conventional electrodialysis unit with two compartments: the dilute and the concentrate. ED cell was made by two polypropylene blocks supporting electrodes. One electrode was made of $\mathrm{Pt} / \mathrm{Ir}$-coated $\mathrm{Ti}$ stretched (anode) and the other of Ti stretched metal (cathode). The membranes and spacers were stacked between the two electrode-end blocks. The ED stack was formed by 10 repeating sections called cell pairs. A cell pair consists of the following: 
Table 1 Physicochemical characteristics of brackish water sample

\begin{tabular}{lll}
\hline Physicochemical Parameters & $\begin{array}{l}\text { Brackish } \\
\text { water } \\
\text { sample }\end{array}$ & $\begin{array}{l}\text { Recommended } \\
\text { values by WHO } \\
\text { (Fewtrell and } \\
\text { Bartram 2008) }\end{array}$ \\
\hline Conductivity at $25^{\circ} \mathrm{C}\left(\mathrm{mS} \mathrm{cm}^{-1}\right)$ & 2.5 & 0.5 \\
$\mathrm{pH}$ & 7.2 & $6.5-8.5$ \\
$\mathrm{TDS}\left(\mathrm{mg} \mathrm{L}^{-1}\right)$ & 2133 & 500 \\
$\mathrm{Cl}^{-}\left(\mathrm{mg} \mathrm{L}^{-1}\right)$ & 300 & 250 \\
$\mathrm{HCO}_{3}{ }^{-}\left(\mathrm{mg} \mathrm{L}^{-1}\right)$ & 197 & - \\
$\mathrm{SO}_{4}{ }^{2-}\left(\mathrm{mg} \mathrm{L}^{-1}\right)$ & 917.46 & 400 \\
$\mathrm{~F}^{-}\left(\mathrm{mg} \mathrm{L}^{-1}\right)$ & 3.66 & 1.5 \\
$\mathrm{NO}_{3}{ }^{-}\left(\mathrm{mg} \mathrm{L}^{-1}\right)$ & 54.2 & 50 \\
$\mathrm{~K}^{+}\left(\mathrm{mg} \mathrm{L}^{-1}\right)$ & 8.075 & 12 \\
$\mathrm{Na}^{+}\left(\mathrm{mg} \mathrm{L}^{-1}\right)$ & 292.4 & 250 \\
$\mathrm{Ca}^{2+}\left(\mathrm{mg} \mathrm{L}^{-1}\right)$ & 188.8 & - \\
$\mathrm{Mg}^{2+}\left(\mathrm{mg} \mathrm{L}^{-1}\right)$ & 211.9 & - \\
\hline
\end{tabular}

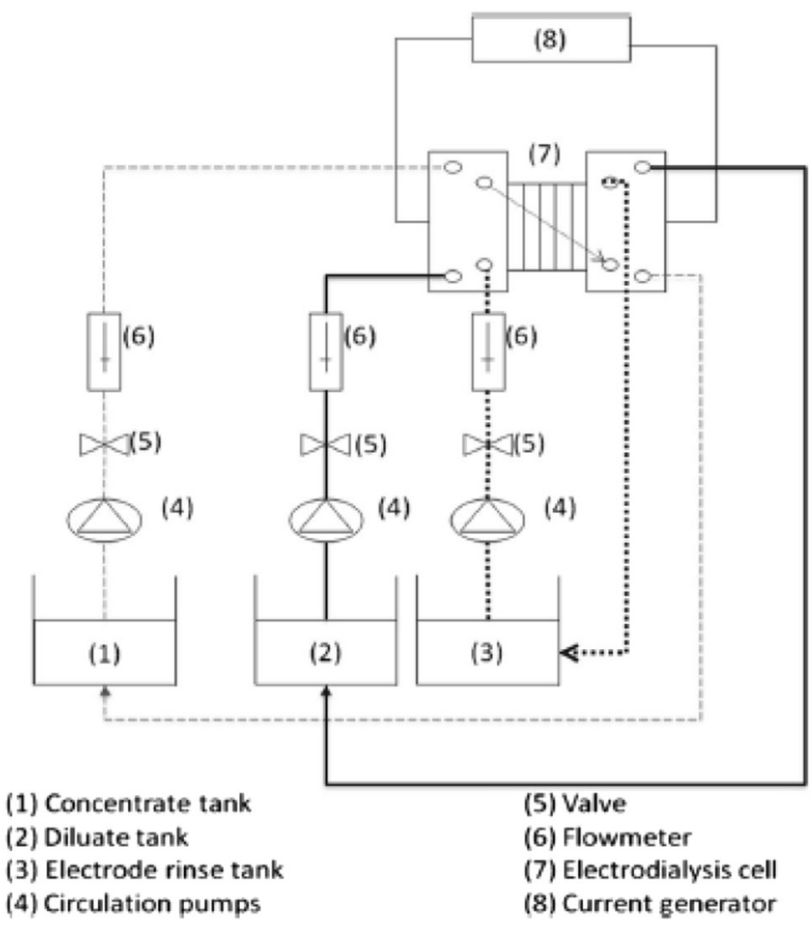

Fig. 1 Scheme of the ED installation

- cation exchange membrane (PC-SK);

- dilute flow spacer $(0.5 \mathrm{~mm})$;

- anion exchange membrane (PC-SA);

- concentrate flow spacer $(0.5 \mathrm{~mm})$.

Spacers were made in plastic and were placed between the membranes to form the flow paths of the dilute and concentrate streams. The spacers were designed to minimize boundary layer effects and were arranged in the stack so that all the dilute and concentrate streams are manifold separately. For each membrane, the active surface area was $64 \mathrm{~cm}^{2}$. The flow channel width between two membranes was $0.5 \mathrm{~mm}$ determined by the thickness of intermembrane spacers. The main characteristics of used membranes are given in Table 2, which were supported by the manufacturer. The stack was equipped with three separate external plastic reservoirs: the first served to concentrate solution, the second to dilute solution and the third to rinse electrode solution. The fluid circulation was achieved using three pumps equipped with flow-meters. Experiments were performed in batch recirculation mode at room temperature.

\section{Experimental procedure}

During all experiments, the volume of dilute, concentrate and rinsing electrode solutions was $1 \mathrm{~L}$ each. $0.1 \mathrm{M} \mathrm{Na}_{2-}$ $\mathrm{SO}_{4}$ was used as electrode rinse solution circulating in electrode compartment, to prevent the generation of chlorine or hypochlorite, which could be hazardous for the electrodes. Flow rate of electrode rinse solution was fixed at $100 \mathrm{~L} \mathrm{~h}^{-1}$ for all experiments. However, the dilute flow rate solution was varied between 20 and $90 \mathrm{~L} \mathrm{~h}^{-1}$ and the concentrate one was fixed at $90 \mathrm{~L} \mathrm{~h}^{-1}$ for all experiments. Before the onset of the desalination test, $\mathrm{NaCl}$ aqueous solution at the same concentration was introduced in dilute and concentrate compartments. The experiment started at time of the potential application, which was varied between 5 and $12 \mathrm{~V}$. For these potentials, the ED system operates under the limiting current. Ionic conductivity was recorded in time. It was measured using a consort D 292 conductivity meter equipped with a D292 conductivity cell. Prior to ED experiment, the conductivity cell was calibrated at $298 \mathrm{~K}$ with $\mathrm{KCl}$ standard solution at 0.01 and $0.1 \mathrm{M}$ of 1.4 and $\quad 12.67 \mathrm{mS} \mathrm{cm}^{-1}$, respectively (cell constant $=0.5 \mathrm{~cm}^{-1}$ ). Dilute and concentrate solutions were circulated through the ED cell until the desired product conductivity $\left(\approx 0.5 \mathrm{mS} \mathrm{cm}^{-1}\right)$ was achieved in the dilute one. This value is equivalent to the good quality water. After every experiment, ED cell was cleaned with circulation of $0.1 \mathrm{M} \mathrm{HCl}$ solution during $15 \mathrm{~min}$ to remove any deposits, followed by circulation of distilled water.

\section{Analytical method}

$\mathrm{Na}^{+}$and $\mathrm{K}^{+}$were analyzed by atomic emission spectroscopy using a "Sherwood 410" spectrophotometer. $\mathrm{Ca}^{2+}$ and $\mathrm{Mg}^{2+}$ amounts were determined using a conventional colorimetric EDTA titration. $\mathrm{HCO}_{3}{ }^{-}$was determined using a conventional colorimetric sulphuric acid $\left(\mathrm{H}_{2} \mathrm{SO}_{4}\right)$ titration. Nitrate concentration was measured by UV spectrophotometric method. Chloride analysis was measured by potentiometric titration using an automatic titrator (Metrohm 809). Sulphate concentration was 
Table 2 Characteristics of the PC cell standard cation and anion exchange membranes

\begin{tabular}{|c|c|c|c|c|c|c|}
\hline Membranes & $\begin{array}{l}\text { Thickness } \\
(\mu \mathrm{m})\end{array}$ & $\begin{array}{l}\text { Ion exchange capacity } \\
\left(\text { meq } \mathrm{g}^{-1}\right)\end{array}$ & $\begin{array}{l}\text { Chemical stability } \\
(\mathrm{pH})\end{array}$ & Permselectivity & $\begin{array}{l}\text { Functional } \\
\text { groups }\end{array}$ & $\begin{array}{l}\text { Membrane resistance } \\
\left(\Omega \mathrm{cm}^{2}\right)\end{array}$ \\
\hline PC-SK & 130 & $\approx 1$ & $0-11$ & 0.96 & $-\mathrm{SO}_{3}{ }^{-}$ & $0.75-3$ \\
\hline PC-SA & $90-130$ & $\approx 1.5$ & $0-9$ & 0.93 & $-\mathrm{NH}_{4}^{+}$ & $1-1.5$ \\
\hline
\end{tabular}

determined by gravimetric analysis using $\mathrm{BaCl}_{2}$ in acidified medium. Fluoride concentration was determined using ion selective electrode (ISE 6.0502.150 fluoride ion electrode) in conjunction with a standard reference electrode connected to a Metrohm $781 \mathrm{pH} /$ Ion-meter. To avoid possible interference resulting from changes in solution $\mathrm{pH}$ and conductivity, a total ionic strength adjustment buffer (TISAB) solution was used. It contained $58 \mathrm{~g}$ of $\mathrm{NaCl}$ and $57 \mathrm{~mL}$ of glacial acetic acid and their $\mathrm{pH}$ was regulated at 5.5 value using $\mathrm{NaOH}$. The fluoride samples and the fluoride standard were diluted by addition of TISAB solution with a molar ratio of $1: 1 . \mathrm{pH}$ meter (consort D 291) was used for measuring $\mathrm{pH}$ solutions.

\section{Data analysis}

To investigate the influence of the salt concentration, applied potential and flow rate on the ED efficiency, the DR was calculated after 12 min of ED application using the following equation (Elmidaoui et al. 2001):

$\operatorname{DR}(\%)=100\left[1-\left(\frac{S_{t}}{S_{0}}\right)\right]$,

where $S_{t}\left(\mathrm{mg} \mathrm{L}^{-1}\right)$ is the salinity in the dilute compartment and $S_{0}\left(\mathrm{mg} \mathrm{L}^{-1}\right)$ is the initial salinity in the feed phase. The salinity was calculated from conductivity (Rodier et al. 2009).

The specific power consumption (SPC) is also an important parameter of electrodialytic desalination. It can be described as the energy needed to treat unit volume of solution. The SPC was calculated for each experimental condition using the following equation (Kabay et al. 2008).

$\mathrm{SPC}=\frac{E \int_{0}^{t} I(t) d \mathrm{t}}{V_{\mathrm{D}}}$,

where $E$ is the applied potential, $I$ is the current, $V_{\mathrm{D}}$ is the volume of dilute stream and $t$ is the time.

\section{Statistical method}

Factorial design determines the effect of multiple variables on a specific response and it can be used to reduce the number of experiments in which multiple factors must be investigated simultaneously (Montgomery 2001). In experimental design, responses are measured at all combinations of the experimental parameters levels. This statistical design methodology allows measuring not only the main effect of each parameter, but also the interaction effect among all the parameters. The determination of interaction effects of parameters may be important for successful system optimization (Montgomery 2001). Today, the most used experimental design is the $2^{n}$ factorial designs, where each variable is investigated at two levels.

In this study, a $2^{3}$ full factorial design was carried out to investigate the performance of the ED process to reduce salt concentration from brackish water. Initial salt concentration $(C)$, dilute feed flow rate $(Q)$ and applied potential $(E)$ were chosen as a relevant parameters for ED optimization. The responses were expressed in terms of percent of demineralization rate (DR) and specific power consumption (SPC). Operating parameters, experimental range and coded levels are given in Table 3.

A total of 12 experiments were performed according to a two level-three factor $\left(2^{3}\right)$ full factorial ( 8 points of the factorial design and 4 center points to establish the experimental errors). The chosen variables for this work were set at two levels and coded as $(+1)$ and $(-1)$ for high and low level, respectively. Since interactions between these factors could be important, a linear polynomial model with first order was postulated by the following equation Eq. (3):

$$
\begin{aligned}
Y= & \beta 0+\beta_{1} E+\beta_{2} C+\beta_{3} Q+\beta_{12} E . C+\beta_{13} E . Q \\
& +\beta_{23} C \cdot Q+\beta_{123} E . C . Q,
\end{aligned}
$$

where $Y$ is the response, $\beta_{0}$ is the constant term, $\beta_{1}, \beta_{2}$ and $\beta_{3}$, are the linear coefficients which indicate the effect of applied potential $(E)$, salt concentration $(C)$ and flow rate $(Q)$, respectively. Coefficients $\beta_{12}, \beta_{13}, \beta_{23}$ describe the interacting effects of applied potential-salt concentration, applied potential-flow rate and salt concentration-flow rate. Coefficient $\beta_{123}$ implies the interacting effect of applied potential-salt concentration-flow rate, while the $E, C$ and $Q$ are the independent coded variables (Turan et al. 2011).

The analysis of experimental results was achieved with statistical and graphical analysis software (Minitab Release 16, 2006). This software was used for regression analysis of the data obtained and to estimate the coefficients of regression equations. 
Table 3 Experimental range and levels of independent variables

Variable real values of coded levels

\begin{tabular}{lcll}
\hline & Low $(-1)$ & Central point $(0)$ & High $(+1)$ \\
\hline$E(\mathrm{~V})$ & 5 & 8.5 & 12 \\
$C\left(\mathrm{~g} \mathrm{~L}^{-1}\right)$ & 1 & 5.5 & 10 \\
$Q\left(\mathrm{~L} \mathrm{~h}^{-1}\right)$ & 20 & 55 & 90 \\
\hline
\end{tabular}

\section{Results and discussions}

\section{Statistical analysis and modeling}

A series of experiments were conducted by considering the $2^{3}$ full factorial design. Table 4 presents the experimental responses measured at two levels of the studied parameters.

As shown by Table 4, the best combination of the factors for the highest demineralization rate occurs at run 6 where a higher applied potential, a lower salt concentration and a higher flow rate are used. This result agrees with that obtained in the previous studies (Kabay et al. 2002; Banasiak et al. 2007; Kabay et al. 2008; Shady et al. 2012).

Concerning the SPC, the values varied between 0.4 and 15.96 $\mathrm{Wh} \mathrm{L}^{-1}$. The lowest value of the SPC was obtained during the runs 3 and 5. The increase of salt concentration and applied potential determined an increase of SPC. Similar result was observed by Ben Sik Ali et al. (2010a) and Kabay et al. (2002). Whereas a slight variation of SPC was observed when flow rate varied from low to high value. This result was in accordance with those of Kabay et al. (2002) which have reported that there is no any considerable effect of flow rate on the SPC.

A linear regression model was fitted for the experimental data using the Minitab statistical software. It was used to investigate the main effects of factors, the interactions, the coefficient standard deviations and various statistical parameters of the fitted models. These parameters, for each response (DR and SPC) are shown in Tables 5 and 6.

The effect is the difference between the responses of two levels (high and low level) of factors; the regression model coefficients are obtained by dividing the effects by two. The standardized effects $(T)$ are obtained by dividing the regression coefficients by the standard error coefficient (Alimi et al. 2014). Substituting the coefficients $\beta$, in Eq. (3) by the respective values from Tables 5 and 6 , we get:

$$
\begin{aligned}
\mathrm{DR}= & 47.06+20.92 E-13.05 C+4.17 Q-0.73 E . C \\
& +0.5 E . Q+0.67 C . Q+3.51 E . C . Q \\
\mathrm{SPC}= & 5.4437+4.9062 E+2.2063 C-0.3862 Q \\
& +2.1438 E-0.4237 E Q-0.1687 C . Q \\
& -0.2812 E . C . Q
\end{aligned}
$$

The $p$ value is the probability value that is used to determine the effects in the model that are statistically significant. The significance of the data is judged by its $p$ value being closer to zero. For a $95 \%$ confidence level the $p$ value should be less than or equal to 0.05 for the effect to be statistically significant (Alimi et al. 2014). The Pareto plot presents the absolute values of the effects of main factors and the effects of interaction of factors. A reference line is drawn to indicate that factors which extend past this line are potentially important (Antony 2003). The effects that are above the reference line are statistically significant at $95 \%$ confidence level. It can be seen from Figs. 2 and 3 that applied potential had the greatest effect on the DR and SPC.

Based on data presented in Table 5 and graphical Pareto chart in Fig. 2, the effect of interaction of two factors which were statistically insignificant was discarded. The final empirical model for DR in term of coded parameters is given by Eq. (6):

$\mathrm{DR}=47.06+20.92 E-13.05 C+4.17 Q+3.51 E . C . Q$

And based on data presented in Table 6 and graphical Pareto chart in Fig. 3, the final empirical model for SPC in term of coded variables is given by Eq. (7):

$$
\begin{aligned}
\mathrm{SPC}= & 5.4437+4.9062 E+2.2063 C-0.3862 Q \\
& +2.1438 E . C-0.4237 E . Q-0.1687 C . Q \\
& -0.2812 E . C . Q
\end{aligned}
$$

The goodness of fit of the model was evaluated by the coefficient of determination $\left(R^{2}\right)$. The determination of very useful $R^{2}$ is allowed by calculation of the ratio of the sum of squares of the predicted responses to the sum of squares of the observed responses (Srinivasan and Viraraghavan 2010). It is suggested that $R^{2}$ should be close to 1 for a good fit model (Boubakri et al. 2013). The estimated model for both DR and SPC had satisfactory $R^{2}$ more than $99 \%$. In the case of DR, fitting is very good $\left(R^{2}=99.75 \%\right)$ and only $0.25 \%$ of total variance was not explained by the model. For the SPC $\left(R^{2}=99.99 \%\right)$, which presents a high value and only $0.01 \%$ of a total variance was not explained by the model.

\section{Main effects plot}

The main effects are shown in Figs. 4 and 5, for DR and SPC, respectively. It indicates the relative strength of effects of various factors. A main effect is present when the mean response changes across the level of a factor. The sign of the main effect indicates the direction of the effect (Srinivasan and Viraraghavan 2010).

As shown in Fig. 4, the potential had a positive effect on desalination efficiency. In fact an increase of applied 
Table 4 Full factorial design matrix for desalination efficiency

\begin{tabular}{llllll}
\hline Run order & $E(\mathrm{~V})$ & $C\left(\mathrm{~g} \mathrm{~L}^{-1}\right)$ & $Q\left(\mathrm{~L} \mathrm{~h}^{-1}\right)$ & $\mathrm{DR}(\%)$ & $\mathrm{SPC}\left(\mathrm{Wh} \mathrm{L}^{-1}\right)$ \\
\hline 1 & 5 & 1 & 20 & 31.95 & 0.55 \\
2 & 12 & 1 & 20 & 81.26 & 6.36 \\
3 & 5 & 10 & 20 & 13 & 0.45 \\
4 & 12 & 10 & 20 & 45.35 & 15.96 \\
5 & 5 & 1 & 90 & 44.95 & 0.4 \\
6 & 12 & 1 & 90 & 82.24 & 5.64 \\
7 & 5 & 10 & 90 & 14.64 & 0.75 \\
8 & 12 & 10 & 90 & 63.05 & 13.44 \\
9 & 8.5 & 5.5 & 55 & 64.39 & 5.35 \\
10 & 8.5 & 5.5 & 55 & 61.71 & 5.18 \\
11 & 8.5 & 5.5 & 55 & 59.09 & 5.44 \\
12 & 8.5 & 5.5 & 55 & 62.3 & 5.35 \\
\hline
\end{tabular}

Table 5 Estimated effects and coefficients for DR (coded units)

\begin{tabular}{lrrrr}
\hline Term & Effect & Coefficient & \multicolumn{1}{l}{$T$} & $p$ value \\
\hline Constant & & 47.06 & 60.98 & 0.000 \\
$E$ & 41.84 & 20.92 & 27.11 & 0.000 \\
$C$ & -26.09 & -13.05 & -16.91 & 0.000 \\
$Q$ & 8.33 & 4.17 & 5.40 & 0.012 \\
E.C & -1.46 & -0.73 & -0.95 & 0.414 \\
E. $Q$ & 1.01 & 0.50 & 0.65 & 0.560 \\
C. $Q$ & 1.34 & 0.67 & 0.87 & 0.449 \\
E.C.Q & 7.02 & 3.51 & 4.55 & 0.020
\end{tabular}

Standard error coefficient for all cases $=0.7716$

$R^{2}=0.9975$

Table 6 Estimated effects and coefficients for SPC (coded units)

\begin{tabular}{lrrrr}
\hline Term & Effect & Coefficient & \multicolumn{1}{l}{$T$} & $p$ value \\
\hline Constant & & 5.4437 & 141.74 & 0.000 \\
$E$ & 9.8125 & 4.9062 & 127.75 & 0.000 \\
$C$ & 4.4125 & 2.2063 & 57.45 & 0.000 \\
$Q$ & -0.7725 & -0.3862 & -10.06 & 0.002 \\
E.C & 4.2875 & 2.1438 & 55.82 & 0.000 \\
E. $Q$ & -0.8475 & -0.4237 & -11.03 & 0.002 \\
C.Q & -0.3375 & -0.1687 & -4.39 & 0.022 \\
E.C.Q & -0.5625 & -0.2812 & -7.32 & 0.005 \\
\hline
\end{tabular}

Standard error coefficient for all cases $=0.03841$

$R^{2}=0.9999$

potential from low to high level resulted in increasing DR by $41.84 \%$.

At higher salt concentration values, it can be observed that the DR has a considerable dependence on the feed solution in the range of $5.5-10 \mathrm{~g} \mathrm{~L}^{-1}$. Effectively at some

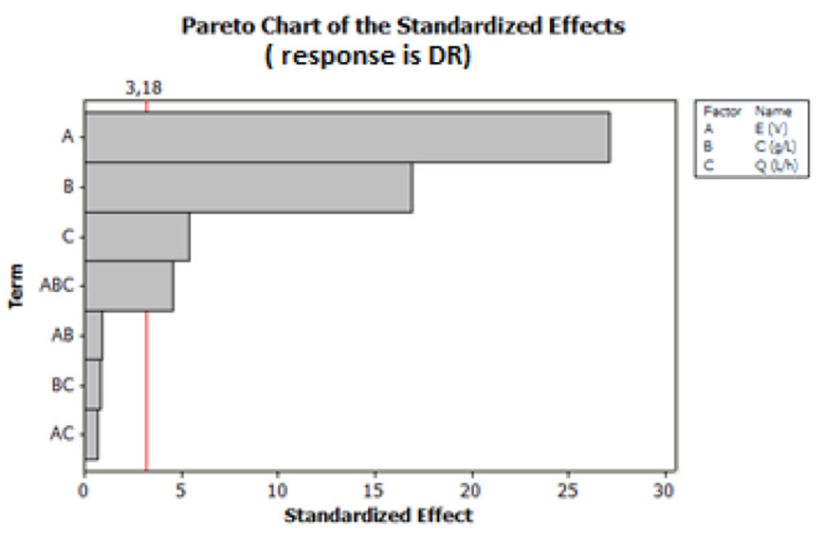

Fig. 2 Pareto chart for standardized effects for DR

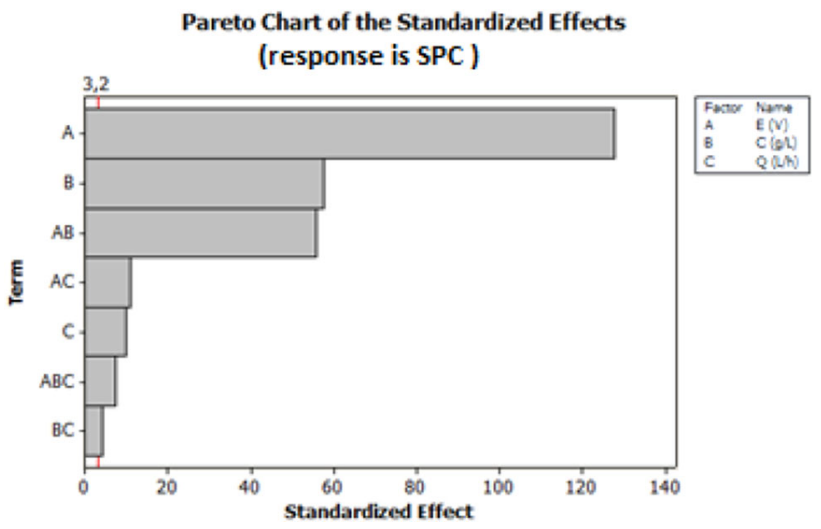

Fig. 3 Pareto chart for standardized effects for SPC

hydrodynamic and electrical conditions an increase of the initial salt concentration leads to a decrease of the DR. This result can be explained by the concentration polarization phenomenon which is more important at high concentration (Sadrzadeh and Mohammadi 2008). As demonstrated in previous studies (Kabay et al. 2002; Banasiak et al. 2007; Sadrzadeh and Mohammadi 2008; Ben Sik Ali et al. 2010a), the number of ions transported through the membranes are almost the same but total amounts of salts are quite different from the different treated solution. As known, the calculation of DR depends strongly on the initial feed concentration and the amount of transported ions. So, the DR evolves reciprocally to the initial feed concentration at some hydrodynamic and electrical conditions. Increasing concentration from low to high level resulted in 26\% decrease in DR (Fig. 4).

At high flow rate, the increase in the DR with flow rate may be attributed to the decrease in the thickness of the boundary layers adjacent to the membranes surfaces with increasing solution velocity. In the present case, Fig. 4 shows a slight increase (8.33\%) in DR when flow rate increases from low to high level likely because the thickness of the boundary layers adjacent to the membranes 


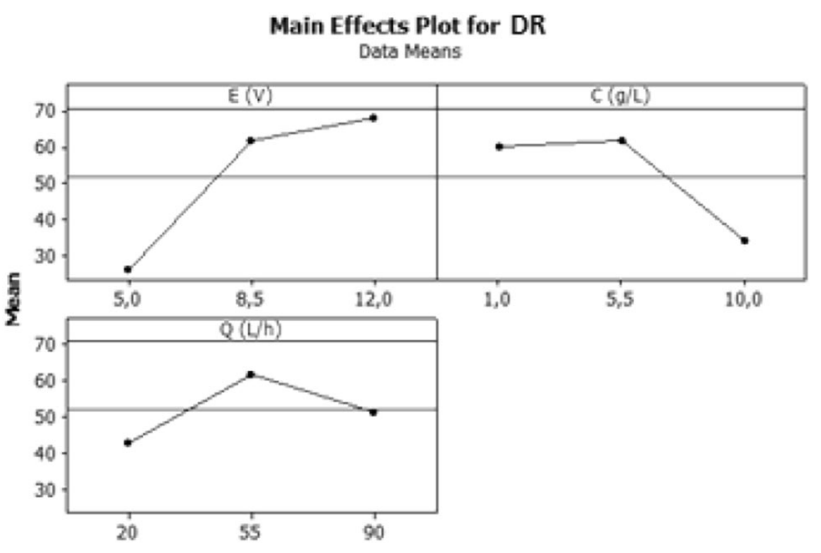

Fig. 4 Main effects plot for DR

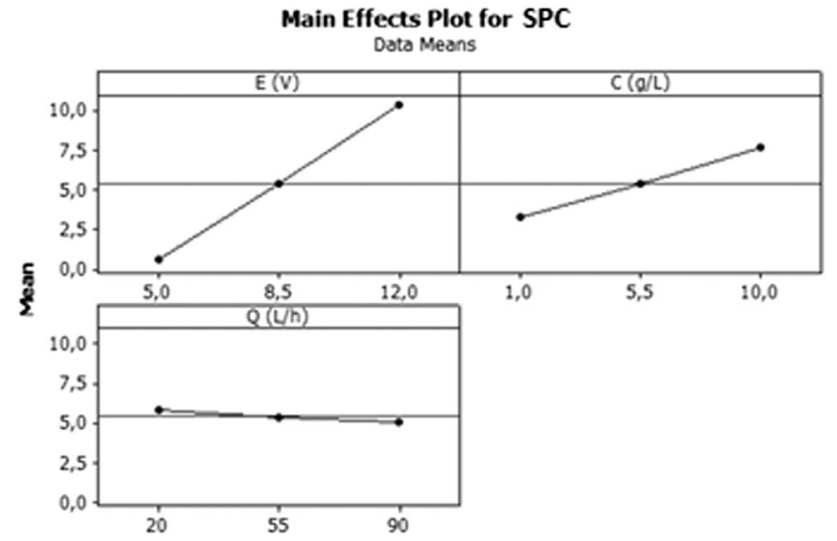

Fig. 5 Main effects plot for SPC

surfaces does not change significantly when flow rates vary from 20 to $90 \mathrm{~L} \mathrm{~h}^{-1}$. Similar results were demonstrated by Kabay et al. (2002).

In the case of SPC, applied potential and the initial salt concentration have a positive effect on this response. But the flow rate had a slight negative one. As a general trend, an increase of applied potential and initial salt concentration from low to high level resulted in increasing SPC by 9.81 and $4.41 \mathrm{Wh} \mathrm{L}^{-1}$, respectively.

\section{Interaction effects plot}

The interaction plot is a graphical tool which plots the mean response of two factors at all possible combination of their settings. If the lines are non-parallel, it is an indication of interaction between the two factors (Antony 2003). Parallel lines indicate that there is no interaction between two factors. The interaction effect plots are shown in Figs. 6 and 7, for DR and SPC, respectively.

In the case of DR, there are no significant interactions between all factors. In the case of SPC, Fig. 7 shows positive interaction between applied potential and salt

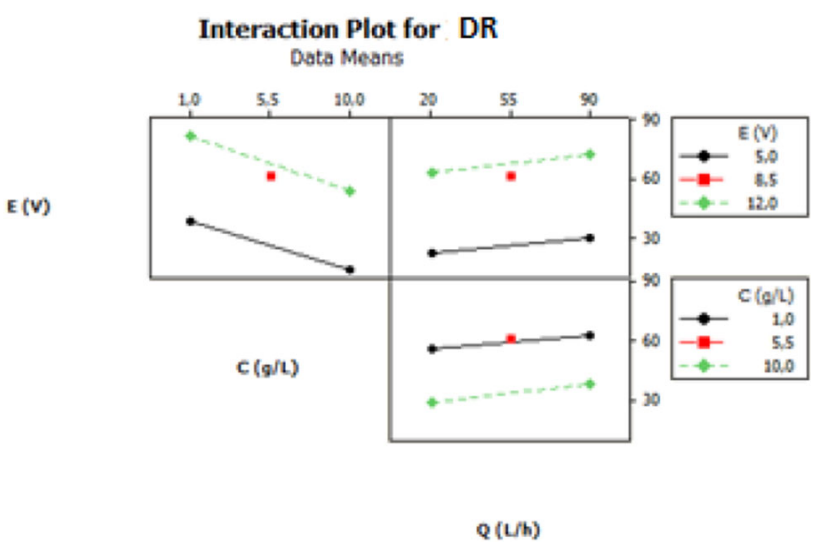

Fig. 6 Interaction effects plot for DR

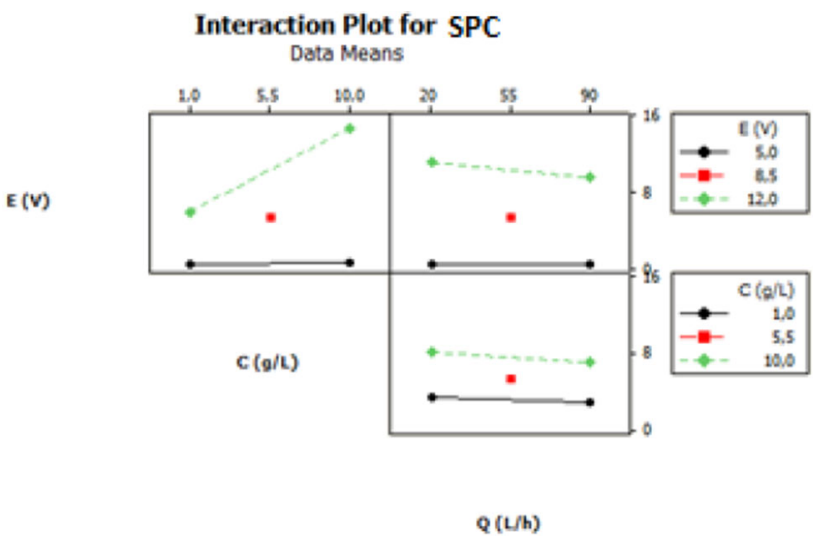

Fig. 7 Interaction effects plot for SPC

concentration. But a negative interactive effect was observed between applied potential and flow rate as well as between salt concentration and flow rate. An increase of the concentration value from 1 to $10 \mathrm{~g} \mathrm{~L}^{-1}$ increased the SPC by $11 \mathrm{Wh} \mathrm{L}^{-1}$ (from 4 to $15 \mathrm{Wh} \mathrm{L}^{-1}$ ) at $12 \mathrm{~V}$. Increasing the flow rate from 20 to $90 \mathrm{~L} \mathrm{~h}^{-1}$ enhances the decrease of SPC by $2 \mathrm{Wh} \mathrm{L}^{-1}$ (from 12 to $10 \mathrm{Wh} \mathrm{L}^{-1}$ ) at $12 \mathrm{~V}$. Also, the increase of flow rate from low to high level decreases the SPC value by $1 \mathrm{Wh} \mathrm{L}^{-1}$ (from 8 to $7 \mathrm{Wh} \mathrm{L}^{-1}$ ) at $10 \mathrm{~g} \mathrm{~L}^{-1}$.

\section{Normal probability plot of residuals}

One of the key of assumptions for the statistical analysis of data from experiments is that the data that come from a normal distribution (Antony 2003). The normality of the data can be checked by plotting a normal probability plot of the residuals. If the points on the plot fall fairly close to a straight line, the data are normally distributed (Antony 2003). The normal probability plot of the residuals with a 95\% confidence level for DR and SPC are shown in Figs. 8 and 9. It can be seen that for DR and SPC, the experimental 
Fig. 8 Normal probability plot of the residuals for DR
Normal Probability Plot

( response is DR)

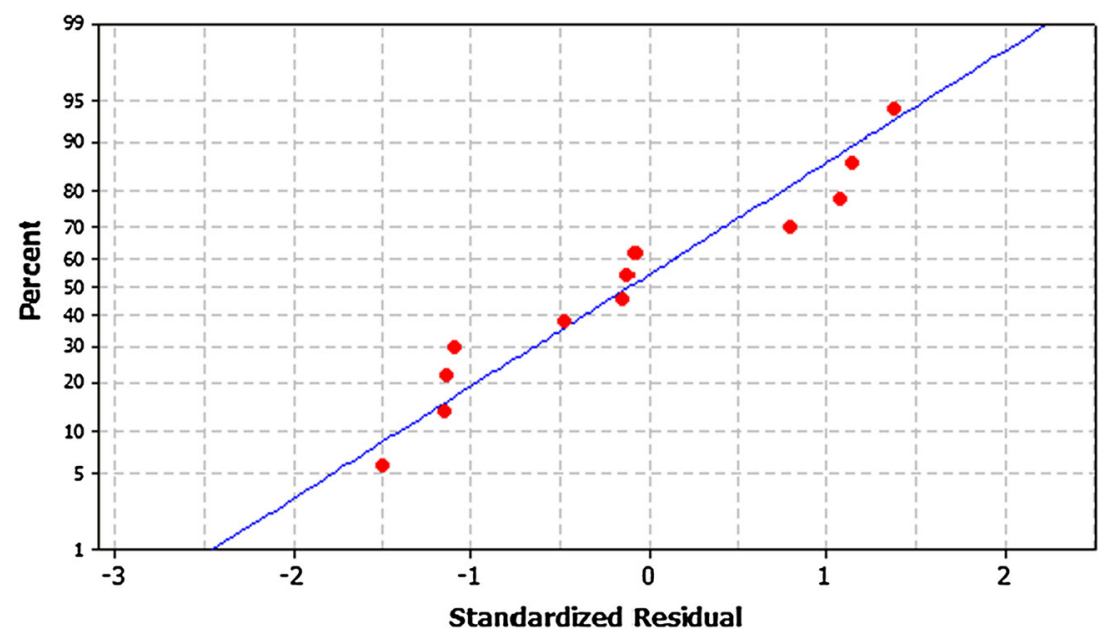

Normal Probability Plot

( response is SPC)

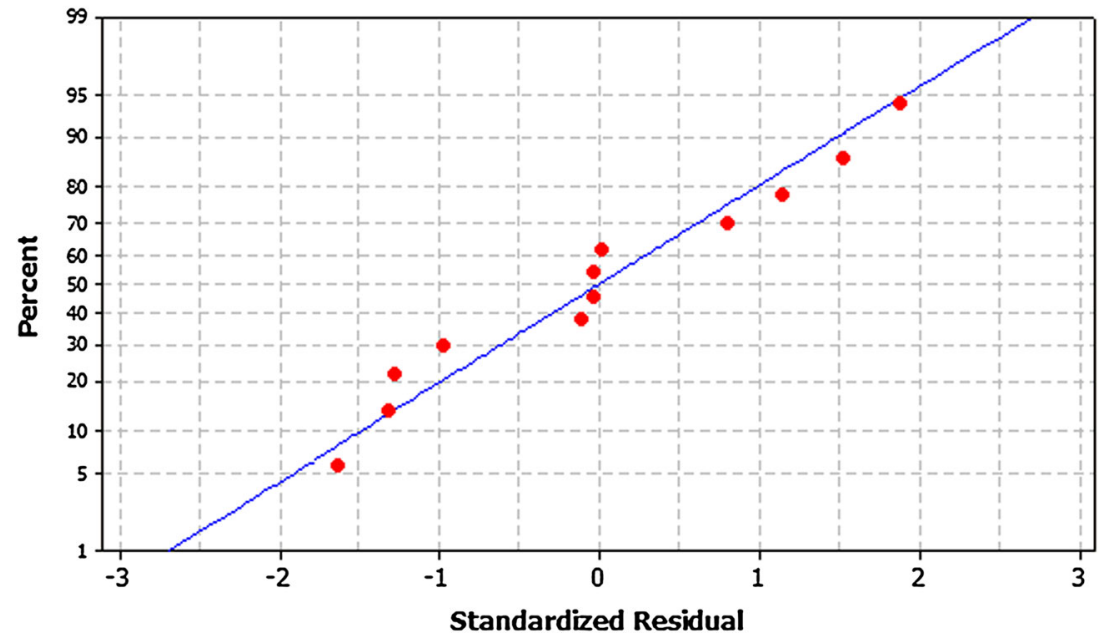

points fall fairly close to the straight line. Therefore, the data from the experiments come from a normally distributed population, and they were reliable.

\section{Treatment of the real water sample}

Finally, the application of electrodialysis was performed on the real brackish water (Table 1) using the optimal parameters. The flow rate and applied potential were fixed at $90 \mathrm{~L} \mathrm{~h}^{-1}$ and $12 \mathrm{~V}$, respectively. The physicochemical characteristics of treated water are given in Table 8 . Then, the results were compared with those obtained using classical method of optimization $\left(E=18 \mathrm{~V}, Q=40 \mathrm{~L} \mathrm{~h}^{-1}\right)$ (Table 7).

As shown in Fig. 10 which describes the polarization curve for the real water sample, for the applied potential of
$12 \mathrm{~V}$ at $90 \mathrm{~L} \mathrm{~h}^{-1}$ or $18 \mathrm{~V}$ at $40 \mathrm{~L} \mathrm{~h}^{-1}$, the value of limit current density was not reached. $\mathrm{pH}$ variation due to the reaction of water dissociation into $\mathrm{H}_{3} \mathrm{O}^{+}$and $\mathrm{OH}^{-}$is then avoided and this limits the probability of fouling and/or scaling formation.

Desalination of brackish water was achieved and the concentrations of different species in the obtained treated water are below the amount recommended by WHO. An $85.5 \%$ of DR was obtained after 24 min of ED application with $14.76 \mathrm{Wh} \mathrm{L}^{-1}$ of SPC for $E=18 \mathrm{~V}$ and $Q=40 \mathrm{~L} \mathrm{~h}^{-1}$. Whereas, DR tends to $84 \%$ obtained after 27 min of ED application with $6.72 \mathrm{Wh} \mathrm{L}^{-1}$ of SPC for $E=12 \mathrm{~V}$ and $Q=90 \mathrm{~L} \mathrm{~h}^{-1}$. So, we can clearly observe the advantage of full factorial design which manifests in decreasing SPC. 
Table 7 Optimization of factors influencing the ED efficiency by the classical method optimization

\begin{tabular}{lc}
\hline Effect of applied potential for $C=3 \mathrm{~g} \mathrm{~L}^{-1}$ and $Q=40 \mathrm{~L} \mathrm{~h}^{-1}$ \\
$E(\mathrm{~V})$ & $\mathrm{DR}(\%)$ \\
5 & 25 \\
7 & 50 \\
10 & 57.37 \\
15 & 81.81 \\
18 & 86.88 \\
Effect of flow rate for $C=3 \mathrm{~g} \mathrm{~L}^{-1}$ & and $E=18 \mathrm{~V}$ \\
$Q\left(\mathrm{~L} \mathrm{~h}^{-1}\right)$ & $\mathrm{DR}(\%)$ \\
20 & 80 \\
30 & 90 \\
40 & 90 \\
50 & 89.47 \\
Effect of salt concentration for $E=18 \mathrm{~V}$ and $Q=40 \mathrm{~L} \mathrm{~h}^{-1}$ \\
$C$ (g L $\left.{ }^{-1}\right)$ & $\mathrm{DR}(\%)$ \\
1 & 81.48 \\
1.5 & 73.91 \\
2 & 73.44 \\
2.5 & 60 \\
3 & 50 \\
5 & 44 \\
\hline
\end{tabular}

Table 8 Physicochemical characteristics of treated water

\begin{tabular}{llll}
\hline $\begin{array}{l}\text { Physicochemical } \\
\text { characteristics }\end{array}$ & $\begin{array}{l}\text { Sample treated } \\
\text { at } E=12 \mathrm{~V}, \\
Q=90 \mathrm{~L} \mathrm{~h}^{-1}\end{array}$ & $\begin{array}{l}\text { Sample treated } \\
\text { at } E=18 \mathrm{~V}, \\
Q=40 \mathrm{~L} \mathrm{~h}^{-1}\end{array}$ & $\begin{array}{l}\text { Recommended } \\
\text { values by WHO }\end{array}$ \\
\hline $\begin{array}{l}\text { Conductivity } \\
\left.(\mathrm{mS} \mathrm{cm})^{-1}\right)\end{array}$ & 0.5 & 0.5 & 0.5 \\
$\mathrm{pH}$ & 6.8 & 6.7 & $6.5-8.5$ \\
$\mathrm{TDS}\left(\mathrm{mg} \mathrm{L}^{-1}\right)$ & 340 & 308 & 500 \\
$\mathrm{Cl}^{-}\left(\mathrm{mg} \mathrm{L}^{-1}\right)$ & 94.66 & 44.37 & 250 \\
$\mathrm{HCO}_{3}^{-}$ & 0 & 0 & - \\
$\quad\left(\mathrm{mg} \mathrm{L}^{-1}\right)$ & & & \\
$\mathrm{SO}_{4}{ }^{2-}\left(\mathrm{mg} \mathrm{L}^{-1}\right)$ & 152.44 & 80.75 & 400 \\
$\mathrm{~F}^{-}\left(\mathrm{mg} \mathrm{L}^{-1}\right)$ & 0.42 & 1.05 & 1.5 \\
$\mathrm{NO}_{3}^{-}\left(\mathrm{mg} \mathrm{L}^{-1}\right)$ & 0.8 & 0.81 & 50 \\
$\mathrm{~K}^{+}\left(\mathrm{mg} \mathrm{L}^{-1}\right)$ & 7 & 0.78 & 12 \\
$\mathrm{Na}^{+}\left(\mathrm{mg} \mathrm{L}^{-1}\right)$ & 20 & 21.44 & 250 \\
$\mathrm{Ca}^{2+}\left(\mathrm{mg} \mathrm{L}^{-1}\right)$ & 37.33 & 20 & - \\
$\mathrm{Mg}^{2+}\left(\mathrm{mg} \mathrm{L}^{-1}\right)$ & 32 & 39.6 & - \\
\hline
\end{tabular}

\section{Conclusions}

The results from the presented study showed that the desalination of brackish water using electrodialysis process is depending on several parameters. A series of full factorial design experiments varying initial salt concentration,

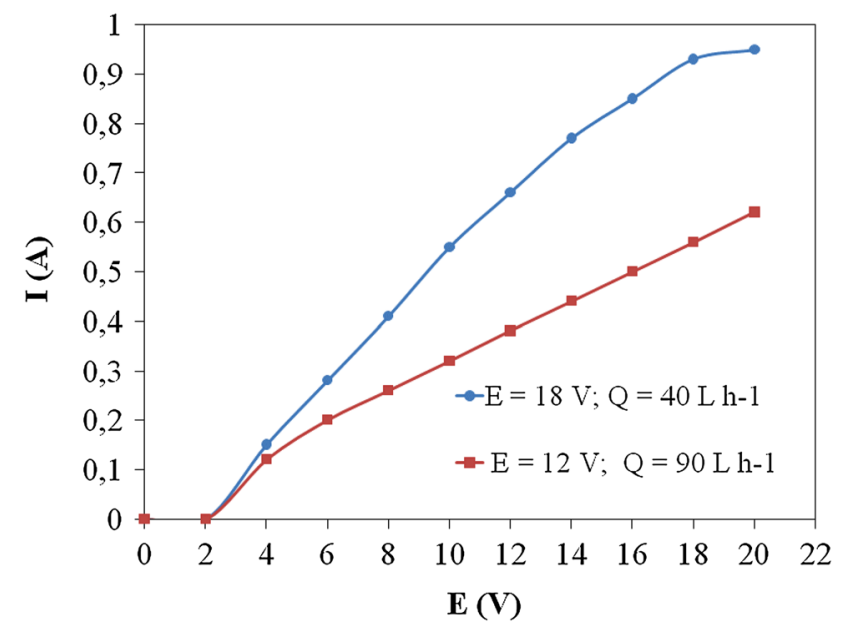

Fig. 10 Polarization curves, $I=f(E)$

applied potential and feed flow rate were performed to optimize the demineralization rate and the specific power consumption.

The applied potential and the salt concentration have a significant effect on the process efficiency and mainly on demineralization rate. It was also found that the decrease of salt concentration induces better performance. On the other hand, the specific power consumption was mostly influenced by initial salt concentration and applied potential. The significant interactions found are between applied potential and salt concentration for the SPC. The factorial experiment design method is undoubtedly a good technique for studying the influence of major process parameters on response factors by significant reducing the number of experiment and henceforth, saving time, energy and money. During this study we were able to obtain high values of demineralization rate going to $82.24 \%$.

Electrodialysis process was applied for the treatment of real brackish water sample. The concentrations of different species in the obtained treated water are below the amounts recommended by World Health organization for drinking water.

Acknowledgements The funding was provided by certe (Grant no. +216 79325122).

Open Access This article is distributed under the terms of the Creative Commons Attribution 4.0 International License (http:// creativecommons.org/licenses/by/4.0/), which permits unrestricted use, distribution, and reproduction in any medium, provided you give appropriate credit to the original author(s) and the source, provide a link to the Creative Commons license, and indicate if changes were made.

Publisher's Note Springer Nature remains neutral with regard to jurisdictional claims in published maps and institutional affiliations. 


\section{References}

Alimi F, Boubakri A, Tlili MM, Amor MB (2014) A comprehensive factorial design study of variables affecting $\mathrm{CaCO}_{3}$ scaling under magnetic water treatment. Water Sci Technol 70:1355-1362. doi: $10.2166 /$ wst.2014.377

Antony J (2003) Design of experiments for engineers and scientists. Butterworth-Heinemann, New York

Azza A, Hamdon A, Darwish NAD, Hilal N (2015) The use of factorial design in the analysis of air-gap membrane distillation data. Desalination 367:90-102

Balbasi M (2013) Application of full factorial design method to silicate synthesis. Mater Res Bull 48:2908-2914

Banasiak LJ, Kruttschnitt TW, Schafer AI (2007) Desalination using electrodialysis as a function of voltage and salt concentration. Desalination 205:38-46

Ben Sik Ali M, Mnif A, Hamrouni B, Dhahbi M (2010a) Electrodialytic desalination of brackish water: effect of process parameters and water characteristics. Ionics 16:621-629

Ben Sik Ali M, Hamrouni B, Dhahbi M (2010b) Electrodialytic defluoridation of brackish water: effect of process parameters and water characteristics. Clean-Soil Air Water 38(7):623-629

Boubakri A, Helali N, Tlili M, Amor MB (2013) Fluoride removal from diluted solutions by Donnan dialysis using full factorial design. Korean J Chem Eng 10:1-6. doi:10.1007/s11814-0130263-9

Elisseeva TV, Shaposhnik VA, Luschik IG (2002) Demineralization and separation of amino acids by electrodialysis with ionexchange membrane. Desalination 149:405-409

Elmidaoui A, Elhannouni F, Sahli MAM, Chay L, Elabbassi H, Hafsi M, Largeteau D (2001) Pollution of nitrate in Moroccan ground water: removal by electrodialysis. Desalination 136:325-332

Elmidaoui A, Elhanouni F, Taky M, Chay L, sahli MA, Echihabi L, Hafsi M (2002) Optimization of nitrate removal operation from ground water by electrodialysis. Sep Purif Technol 29:235-244

Fewtrell L, Bartram J (2008) Guidelines for drinking water quality, 3rd edn. World Health Organization, Geneva, pp 375-492

Fidaleo M, Moresi M (2005) Optimal strategy to model the electrodialytic recovery of a strong electrolyte. J Membr Sci 260:90-111

Galama AH, Saakes M, Bruning H, Rijnaarts HHM, Post JW (2014) Seawater predesalination with electrodialysis. Desalination 342:61-69

Ghyselbrecht K, Huygebaert M, Bruggen BV, Ballet R, Meesschaert B, Pinoy L (2013) Desalination of an industrial saline water with conventional and bipolar membrane electrodialysis. Desalination 318:9-18

Jing G, Du W, Guo Y (2012) Studies on prediction of separation percent in electrodialysis process via BP neural networks and improved BP algorithms. Desalination 291:78-93

Kabay N, Demircioglu M, Ersoz E, Kurucaovali I (2002) Removal of calcium and magnesium hardness by electrodialysis. Desalination 149:343-349

Kabay N, Arar O, Samatya S, Yuksel U, Yuksel M (2008) Separation of fluoride from aqueous solution by electrodialysis: effect of process parameters and other ionic species. J Hazard Mater 153:107-113

Lee HJ, Strathmann H, Moon SH (2006) Determination of the limiting current density in electrodialysis desalination as an empirical function of linear velocity. Desalination 190:43-50
McGovern RK, Weiner AM, Sun L, Chambers CG, Zubair SM, Lienhard JH (2014a) On the cost of electrodialysis for the desalination of high salinity feeds. Appl Energy 136:649-661

McGovern RK, Zubair SM, Lienhard VJH (2014b) Hybrid electrodialysis reverse osmosis system design and its optimization for treatment of highly saline brines. J Desalt Water Reuse 6:15-23

Meski S, Ziani S, Khireddine H, Boudboub S, Zaidi S (2011) Factorial design analysis for sorption of zinc on hydroxyapatite. J Hazard Mater 186:1007-1017

Monohar M, Das AK, Shahi VK (2017) Alternative preparative route for efficient and stable anion exchange membrane for water desalination by electrodialysis. Desalination 413:101-108

Montgomery DC (2001) Design and analysis of experiments, 5th edn. Wiley, New York

Nemati M, Hosseini SM, Shabanian M (2017) Novel electrodialysis cation exchange membrane prepared by 2-acrylamido-2-methylpropane sulfonic acid; heavy metal ions removal. J Hazard Mater 337:90-104

Reig M, Casas S, Aladjem C, Valderrama C, Gibert O, Valero F, Centeno CM, Larrotcha E, Cortina JL (2014) Concentration of $\mathrm{NaCl}$ from seawater reverse osmosis brines for the chlor-alkali industry by electrodialysis. Desalination 342:107-117

Reig M, Casas S, Valderrama C, Gibert O, Cortina JL (2016a) Integration of monopolar and bipolar electrodialysis for valorization of seawater reverse osmosis desalination brines: production of strong acid and base. Desalination 398:87-97

Reig M, Casas S, Gibert O, Valderrama C, Cortina LJ (2016b) Integration of nanofiltration and bipolar electrodialysis for valorization of seawater desalination brines: production of drinking and waste water treatment chemicals. Desalination 382:13-20

Rodier J, Legube B, Merlet N (2009) The analysis of water, 9th edn. Dunod, Paris, pp 78-81

Sadrzadeh M, Mohammadi T (2008) Sea water desalination using electrodialysis. Desalination 221:440-447

Shady AA, Peng C, Bi J, Xu H, Almeria J (2012) Recovery of $\mathrm{Pb}^{2+}$ and removal of $\mathrm{NO}_{3}{ }^{-}$from aqueous solutions using integrated electrodialysis, electrolysis and adsorption process. Desalination 286:304-315

Srinivasan A, Viraraghavan T (2010) Oil removal from water by fungal biomass: a factorial design analysis. J Hazard Mater 175:695-702

Tanaka Y, Reig M, Casas S, Aladjem C, Cortina JL (2015) Computer simulation of ion-exchange membrane electrodialysis for salt concentration and reduction of RO discharged brine for salt production and marine environment conservation. Desalination 367:76-89

Turan NG, Elevli S, Mesci B (2011) Adsorption of copper and Zinc ions on illite: determination of the optimal conditions by the statistical design of experiments. Appl Clay Sci 52:392-399

Walha K, Amar RB, Firdaous L, Quéméneur F, Jaouen P (2007) Brackish groundwater treatment by nanofiltration, reverse osmosis and electrodialysis in Tunisia: performance and cost comparison. Desalination 207:95-106

Zourmand Z, Faridirad F, Kasiri N, Mohammadi T (2015) Mass transfer modeling of desalination through an electrodialysis cell. Desalination 359:41-51 